\title{
PReS-FINAL-2231: A series of 41 mutations of TNFRAF1A
}

\author{
MC Chastang ${ }^{1 *}$, M Desjonqueres ${ }^{1}$, V Hentgen ${ }^{2}$, P Quartier Dit Maire ${ }^{3}, G$ Grateau $^{4}$, I Kone-Paut ${ }^{5}$, I Durieu ${ }^{6}$, J Ninet ${ }^{7}$, \\ P Cochat $^{1}$
}

From 20th Pediatric Rheumatology European Society (PReS) Congress

Ljubljana, Slovenia. 25-29 September 2013

\section{Introduction}

TRAPS (TNF receptor associated periodic syndrome) is a rare autoinflammatory disease that can touch children and adults. It is caused by the mutation of TNFRSF1A encoding for TNF receptor. The main complication is amyloidosis.

\section{Objectives}

The aim is to increase knowledge about the disease to make the diagnostic easier. Another purpose is to analyse the biotherapy treatment in TRAPS.

\section{Methods}

It consists in a retrospective descriptive multicentre study in French and Belgian hospitals. Data were directly collected thanks to files of patients.

Inclusion criteria are: presence of TNFRAF1A mutation, recurrent symptoms. Exclusion criteria: presence of MEFV mutation.

\section{Results}

We have included 25 kids and 16 adults (isolated cases and 9 families), coming from France (45\%), south of Europe (22\%), north of Europe (10\%), Maghreb (9\%), and east of Europe (6\%). Two kids have homozygous mutation for MEFV and one heterozygous. 19,5\% of the patients have had an appendectomy. 26 patients have recurrent fever in their family, among which 22 have TRAPS.

The disease starts mainly before the age of 5 years $(61,1 \%)$ but for $13,5 \%$, it begins in adulthood. The average of the time of diagnosis (delay between first symptoms and diagnosis) is 12,9 years.

${ }^{1}$ Hopital Femme Mère Enfant Chu Lyon, Lyon, France

Full list of author information is available at the end of the article
$51 \%$ of R92Q heterozygous mutation, $10 \%$ of T50M, 7\% de L67P, 5\% C29S, 5\% C43S have been encountered. $2 \%$ of the patients have R92Q homozygous, 2\% Q82R and R92Q heterozygous.

The seizures occur 9,7 times a year on average $(<1$ to 48 times a year), last 10,8 days on average ( 1 to 49 days). A trigger exists in $43.9 \%$ of the cases. $78 \%$ have rheumatologic symptoms, $70,7 \%$ arthralgia (mainly knees, spine, elbows), 22\% arthritis (small and big joints). $24,4 \%$ have chest pain, $7,3 \%$ serositis. Dermatological symptoms $(70,7 \%)$ are frequent $(56,1 \%$ rash). Lots of patients have abdominal pain $(70,7 \%)$, myalgia $(65,7 \%)$, asthenia $(48,8 \%)$. Headache is present in $39 \%$ of this population. Only 3 patients have periorbital oedema. Between the seizures there is no symptomatology, but in $24 \%$ of the cases inflammatory syndrome persists.

We note the interest to dose the Serum Amyloid A to detect the activity of disease between the crises.

The screening of proteinuria was positive in $29 \%$ of the cases but no amyloidis is reported.Correlation between R92Q mutation and hematologic symptoms (splenomegaly, adenopathy) was found between genotype and phenotype.

Corticosteroids were used for treatment of seizures. Only 9 patients were treated by biotherapy. Etanercept was efficient in a first time, but not always in the long term. Anakinra always allowed remission.

\section{Conclusion}

77\% of this population of patients with TNFRSF1A mutation has 3 symptoms among arthralgia, rash, abdominal pain, myalgia, asthenia and headache. Etanercept is not always efficient and Anakinra is a good alternative for the treatment. The inscription of the patients 
in autoinflammatory disease registers would allow a better knowledge of TRAPS.

\section{Disclosure of interest}

None declared.

\section{Authors' details}

${ }^{1}$ Hopital Femme Mère Enfant Chu Lyon, Lyon, France. ${ }^{2} \mathrm{CH}$ Versailles, Versailles, France. ${ }^{3}$ Necker, Paris, France. ${ }^{4}$ Hopital Tenon, Paris, France.

${ }^{5}$ Hopital Kremlin Bicetre, Kremlin Bicetre, Paris, France. ${ }^{6}$ Centre Hospitalier Lyon Sud, Lyon, France. ${ }^{7} \mathrm{HEH}$, Lyon, France.

Published: 5 December 2013

doi:10.1186/1546-0096-11-S2-P221

Cite this article as: Chastang et al:: PReS-FINAL-2231: A series of 41 mutations of TNFRAF1A. Pediatric Rheumatology 2013 11(Suppl 2):P221.

Submit your next manuscript to BioMed Central and take full advantage of:

- Convenient online submission

- Thorough peer review

- No space constraints or color figure charges

- Immediate publication on acceptance

- Inclusion in PubMed, CAS, Scopus and Google Scholar

- Research which is freely available for redistribution

Submit your manuscript at www.biomedcentral.com/submit 